\title{
Comparative study of composition, antioxidant and antimicrobial activity of two adult edible insects from Tenebrionidae family
}

\author{
Daniel R. Flores ${ }^{1}$, Luz E. Casados², Sandra F. Velasco ${ }^{1}$, Ana C. Ramírez ${ }^{1}$ and Gilberto Velázquez ${ }^{1 *}$ (D)
}

\begin{abstract}
In the case of Tenebrionidae family insects, studies focus on larval stage, leaving a lack of information regarding other stages. Therefore, this study was performed in order to understand the differences between the nutritional composition and the bioactivity of two species of this family in their adult stage, fed with a specific diet. Adult beetles of both species were defatted, lyophilized and protein extracted with buffer. Proximal and phytochemical analysis of the extracts of each insect were performed, along with protein extract and hydrolysis analysis by Tris-Tricine and Tris Glycine SDS PAGE. This analysis showed that T. molitor contained more protein and fat than $U$. dermestoides but contained less crude fiber. The protein extraction was made with PBS, where 130 and $45 \mathrm{kDa}$ bands showed predominant for U. dermestoides, and less protein was present for T. molitor. Antioxidant and antimicrobial activities of the enzymatic protein hydrolysates and protein crude extracts were determined. Presence of protein associated with the antioxidant activity were found in both insects. Nonetheless $U$. dermestoides had a higher antioxidant activity with the protein extract in contrast with the higher antioxidant activity shown by $\mathrm{U}$. dermestoides once the extracts were digested. After proteolysis, protein extracts showed an increasing antioxidant activity, plus, the ability to inhibit microbial growth of Proteus, Shigella and Bacillus. Insect protein hydrolysates with protease open the possibility for the use of these beetles as new sources of encrypted peptides for microbiological control once characterized.
\end{abstract}

Keywords: T. molitor, U. dermestoides, Antioxidant activity, Antimicrobial activity, Protein hydrolysates

\section{Introduction}

Entomophagy, the consumption of insects, has been promoted as an alternative sustainable protein source for humans and animals [1]. Insect consumption by humans is an old, historically and geographically, widespread phenomenon. The use of edible insects varies greatly by local preference, sociocultural significance, and region [2]. Recently, European countries have an increased interest in studying insects as potential food sources, but it is still a challenge to gain acceptance in society $[3,4]$. However,

\footnotetext{
*Correspondence: gilberto.velazquez@academicos.udg.mx

${ }^{1}$ Chemistry Department, University of Guadalajara, 1421 Marcelino García Barragán Blvd, 44430 Guadalajara, Jalisco, Mexico

Full list of author information is available at the end of the article
}

in Latin American cultures, especially in Mexico, the consumption of insects is a tradition rooted in the local cuisine; clear examples of this is the consumption of the grasshoppers, ants, and worms. Despite the early acceptance of entomophagy in Mexico, there are not enough studies which promote the use of different edible insects whose cultivation is simple, practical and under controlled conditions which ensure safe consumption [5]. Tenebrio molitor (T. molitor) and Ulomoides dermestoides (U. dermestoides) beetles, whether in larval or adult stage, are harmless, non-toxic and do not bite. These animals invade barns and are considered a plague by many farmers, but when kept in captivity they can be fed with a great variety of foods such as: wheat flour, maize or oats; barley and wheat bran, remnants of meat, dead insects

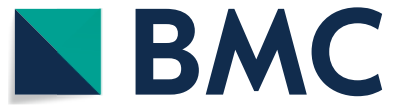

(c) The Author(s) 2020. This article is licensed under a Creative Commons Attribution 4.0 International License, which permits use, sharing, adaptation, distribution and reproduction in any medium or format, as long as you give appropriate credit to the original author(s) and the source, provide a link to the Creative Commons licence, and indicate if changes were made. The images or other third party material in this article are included in the article's Creative Commons licence, unless indicated otherwise in a credit line to the material. If material is not included in the article's Creative Commons licence and your intended use is not permitted by statutory regulation or exceeds the permitted use, you will need to obtain permission directly from the copyright holder. To view a copy of this licence, visit http://creativeco mmons.org/licenses/by/4.0/. The Creative Commons Public Domain Dedication waiver (http://creativecommons.org/publicdomain/ zero/1.0/) applies to the data made available in this article, unless otherwise stated in a credit line to the data. 
and decaying trees. Though in terms of hydration, fruit or vegetables are enough to feed them. T. molitor and $U$. dermestoides belong to family Tenebrionidae, and are distributed all over the planet, especially in regions with temperate climates. Their sizes varies between 1 and $30 \mathrm{~mm}$. Although insects are known for their diverse nutritional properties, specially associated with their high percentage of protein and/or high content of fatty acids (mono and polyunsaturated), they are also rich in minerals such as: copper, iron, magnesium, manganese, phosphorus, selenium, zinc, vitamins such as: riboflavin, pantothenic acid, biotin and folic acid. Authors like Nowak et al. [32] point out that existing information on the contribution of insects to nutrient intake is still too scarce. While, in some extent family Tenebrionidae has been characterized in terms of nutritional value $[6,7]$, protein production [8], cytotoxic and genotoxic activity $[9,10]$, and some nutraceutical properties [11-13]. Aforementioned studies are focused only in the larvae's stage of the insect. This leaves a deficiency regarding the nutritional information and properties associated with the adult stage of the family Tenebionidae. Even more, there is practically no information comparing insects of the same family when they are fed a specific diet. The present study was conducted to understand the differences between the nutritional composition, and bioactivities of two adult edible insects: $T$. molitor and $U$. dermestoides.

\section{Materials and methods}

\section{Methods of edible insect preparation}

Ulomoides dermestoides Chevrolat [13] (=Palembus (Ulomoides) dermestoides, $=$ Martianus dermestoides) it's an arthropod of the order Coleoptera, family Tenebrionidae, tribe diaperinae, genus Ulomoides, species $U$. dermestoides, originary from the southeast of Asia. The taxonomical identity of $U$. dermestoides was obtained following the keys published by Kim \& Jung [14]; Tenebrio molitor [15] it's an arthropod of the order Coleoptera, family Teneobrinidae, species Tenebrio molitor, originally from Europe.

The taxonomical identity of Tenebrio molitor was obtained following the keys published by the National Science Foundation Grants DRL 0089283, DRL 0628151, DUE 0633095, DRL 0918590, and DUE 1122742. Additional support was granted by the Marisla Foundation, UM College of Literature, Science, and the Arts, Museum of Zoology, and from Information and Technology Services at University of Michigan. Both identifications were later validated by Dr. J. Luis Navarrete Hereida responsible of the scarabaeidae and entomology collection at the reservoir from the Botany and Zoology department of the University of Guadalajara's Center of Biological and Agricultural Sciences (CUCBA); CZUG collection.
CUCBA, SNIB CONABIO database, Project EC017 y CE022. México, D. F.

Specimens from the Tenebrionidae family: Adult beetle T. molitor (Linnaeus, Coleoptera: Tenebrionidae) and adult beetle $U$. dermestoides were kindly donated from the identified taxonomic reservoir by Dr. J. Luis Navarrete Hereida and the offspring was deposited in a plastic container where the temperature was maintained between 25 and $30{ }^{\circ} \mathrm{C}$, once at the adult stage, insects were separated into different deposits. Food consisted of a mixture of oats and thin slices of apple (approximately $3.2-4.8 \mathrm{~mm}$ thick) every third day as source of hydration [11]. Insects were fasted for approximately $48 \mathrm{~h}$ to clear their gastrointestinal tract of any residual food before they were collected. Then they were defatted with hexane for $2 \mathrm{~h}$ and set to solvent evaporation. Finally, the samples were frozen with liquid nitrogen and stored at $-70{ }^{\circ} \mathrm{C}$ for further experimentation.

\section{Reagents}

2,2-azino-bis (3-ethylbenzothiazoline-6-sulfonic acid) (ABTS) and 2,2-diphenyl-1-picrylhydrazyl, (DPPH); Aspergillus oryzae protease was purchased from SigmaAldrich. All of the other chemicals used were of analytical grade. Dialysis membranes with $1 \mathrm{kDa}$ and $10 \mathrm{k}$ cut-off were purchased from Spectrum Lab. Culture medium for bacterial growth was Tryptic Soy Broth (TSB) and Tryptic Soy Agar (TSA) from Becton-Dickinson.

\section{Proximate analysis}

All samples were lyophilized and preserved in a freezer at $-80 \mathrm{C}$ (model SC-10 N, brand Scientz). The proximal analysis was performed at the Laboratory of Quantitative Chemical Analysis of the Chemistry Department in the University of Guadalajara's Center of Exact Sciences and Engineering ( $U$ de $G$ ). Following the methods by the Association of Official Analytical Chemist [16], such as AOAC-934.01 for moisture, AOAC-928.08 for Nitrogen content and Protein content estimation, AOAC-920.39 for Fat/Crude fat, AOAC-962.09 for crude fiber and AOAC-923.03 for Ash content.

\section{Qualitative phytochemical analysis}

Extracts of each insect $(0.1 \mathrm{~g} / \mathrm{ml})$ were subjected to preliminary phytochemical screening (acidic, alkaline and neutral aqueous systems were used when necessary) by standard methods [17] for detection of the following constituents: tannins [18], alkaloids, triterpenoids, carbohydrates, steroids [19], saponins, glucosides [20], flavonoids [21], and anthraquinones [22]. 


\section{Protein extract preparation}

Proteins were extracted as follows: $1.0 \mathrm{~g}$ of insects (previously treated as above mentioned) were weighted and extracted with buffer Phosphate-Buffered Saline (PBS) (for most cases unless specified) in 1:9 ratio (insect: buffer), then each sample was sonicated for 5 min (during a $30 \mathrm{~s}$ interval on, and, $15 \mathrm{~s}$ off). The sonicated extract was centrifuged at room temperature for $10 \mathrm{~min}$ at $8000 \mathrm{~g}$, and supernatant was collected; when necessary, acetone (4:1 acetone: supernatant) or ammonium sulfate (30\% saturation) was used for the concentration of protein extract, followed by resuspension in PBS. All the supernatants (either concentrated or not) were subjected to overnight dialysis (using a $10 \mathrm{kDa}$ cut-off membrane). Supernatants were stored at $4{ }^{\circ} \mathrm{C}$ to further analysis.

\section{Tris glycine and Tris tricine SDS-PAGE protein electrophoresis}

Analysis of the extracts were performed on $12 \%$ of SDSPAGE electrophoresis gel according to the protocol established by Laemmli (Tris Glycine system). A MiniProtean BioRad (BioRad, Hercules, CA, USA) electrophoresis system with $20 \mathrm{~mA}$ was used. Samples were mixed with Laemmli buffer $(1: 1, \mathrm{v} / \mathrm{v})$ and heated at $90 \mathrm{C}$ for $5 \mathrm{~min}$ prior to the electrophoresis. Gels were stained with Coomassie Blue R-250 using the thermo molecular marker (page ruler unstained broad range protein ladder and page ruler unstained low range protein ladder). When necessary (peptide visualization) a Tris Tricine system on 16\% of SDS-PAGE was performed according to the protocol of Schägger H [23]. Protein quantification was done using Bradford method [24].

\section{Protease digestion}

Samples were treated with Aspergillus oryzae (A. Ory$z a e)$ protease from sigma (1:200) (protease: sample) in a $500 \mu \mathrm{L}$ reaction volume. Untreated samples, buffer alone, or enzyme solutions were used as controls. Treated samples and controls were incubated at $37^{\circ} \mathrm{C}$ for $24 \mathrm{~h}$. They were then dialyzed on a $1 \mathrm{kDa}$ cut-off membrane (to avoid loss of peptides) against PBS for $2 \mathrm{~h}$ at $4{ }^{\circ} \mathrm{C}$, before its use on antioxidant and antimicrobial activity assays.

\section{ABTS radical scavenging activity}

ABTS Assay $\left(\mathrm{ABTS}^{+}\right)$was determined according to Re et al. [25] with some modifications. The radical ABTS ${ }^{+}$ was chemically generated using ammonium persulfate, diluted in deionized water until a final concentration of $7 \mathrm{mM}$. The solution was diluted to reach an absorbance around 0.7 at $750 \mathrm{~nm}$. In a 96-well microplate, $20 \mu \mathrm{L}$ of sample and $280 \mu \mathrm{L}$ of $\mathrm{ABTS}^{+}$solution was mixed. The absorbance change $(750 \mathrm{~nm})$ was measured after $15 \mathrm{~min}$ of incubation at room temperature. The percentage scavenging activity was calculated according to Eq. 1:

$$
\text { Scavengingactivity }(\%)=\left(\frac{A_{\text {control }}-A_{\text {sample }}}{A_{\text {control }}}\right) \times 100
$$

where: $\mathrm{A}_{\text {sample }}$ is the absorbance of the $\mathrm{ABTS}^{+}$solution with the sample; and $A_{\text {control }}$ is the absorbance of the $\mathrm{ABTS}^{+}$solution without the sample.

\section{Antimicrobial activity}

Samples were assayed by the well diffusion method according to de la Fuente Salcido et al. [26, 27] with some modifications. Briefly: twenty-five mililiters of freshly prepared sterile Tryptic Soy Agar (cooled to $40-50{ }^{\circ} \mathrm{C}$ ) was poured into sterile Petri dishes containing $115 \mu \mathrm{L}$ $\left(1 \times 10^{9}\right.$ cells $\left./ \mathrm{mL}\right)$ of the following bacteria: Micrococcus luteus, Bacillus aerius, Samonella spp., Bacillus wiedmannii, Streptococcus canis, Enterococcus casseliflavus, Bacillus cereus strain JCM 2152, Bacillus cereus strain 183, Listeria monocytogenes and Listeria innocua and Vibrio parahaemolyticus. These bacteria are maintained in a stock collection of microorganisms in our laboratory. Once the mixture solidified, wells of $6 \mathrm{~mm}$ in both diameter and depth were made on the plates using sterile cork borers. $90 \mu \mathrm{L}$ of the prepared sample was then dispensed into the wells, allowed to equilibrate at room temperature for $30 \mathrm{~min}$, and then incubated overnight at $37{ }^{\circ} \mathrm{C}$. Zones of growth inhibition (in $\mathrm{mm}$ ), were measured as the diameter of the clear zones around each well, and, then compared with the antimicrobial standards. All the experiments were done in triplicates and the data is presented as mean values.

\section{Statistical analysis}

The experiments shown are the mean value \pm standard error (SE) of the data from at least three experiments. Statistical analyses were performed using Graph Pad Prism 8 statistical software. Differences with $p$ values of less than 0.05 were considered significant.

\section{Results and discussion} Proximate analysis

Insects are well known to be rich in nutrients: proteins, lipids, carbohydrates, vitamins and minerals [28, 29]. There are several reports suggesting that insects could be an excellent source of protein, since their availability in nature is very abundant and their breeding economically feasible [30]. Composition of adult beetles of T. molitor and $U$. dermestoides are shown in Table 1 . The highest content of protein and fat was found in T. molitor, while in terms of crude fiber $U$. dermestoides had the highest 
Table 1 Physicochemical composition of Tenebroideae beetles $T$. molitor and U.dermestoides

\begin{tabular}{lcc}
\hline & U. dermestoides & T. molitor \\
\hline Ash & $2.12 \pm 0.71$ & $3.24 \pm 1.48$ \\
Protein $(\mathrm{N} \times 6.25)$ & $40.36 \pm 0.79^{*}$ & $54.86 \pm 1.70^{* *}$ \\
Fat & $8.33 \pm 0.69^{*}$ & $12.50 \pm 1.46^{* *}$ \\
Crude fiber & $49.17 \pm 0.32^{*}$ & $26.63 \pm 0.69^{* *}$ \\
NFE & $0.02 \pm 1.38$ & $2.77 \pm 0.94$ \\
\hline
\end{tabular}

Values are expressed as mean \pm standard deviation $(n=3)$. All data are expressed as $\mathrm{g} / 100 \mathrm{~g}$ dry mass, N: Nitrogen

${ }^{*}$ At the exponential, in the same row, show there are significant differences (p-value $<0.05$ )

value. There is no statistical difference between adult beetles in term of ash contents. It is important to notice that all results were expressed in dry mass in order to have a comparative value for other studies.

The protein content found in this work for T. molitor was $54.86 \pm 1.70 \%$ which fits within the range reported in previous studies [31-33]; while the protein found for $U$. dermestoides in this work is slightly lower than the $48.31 \%$ reported by Zhou and Chen [34]. In contrast with the protein content found in other insects' orders, it fits within the range of grasshoppers/locust 40-74.28\%, Lepidoptera (wax moth and butterflies) $14-68 \%$, Hemiptera 42-74\%, Orthoptera (crickets) $55.65-75 \%$ and Diptera (common housefly) 55-70\% [35-38]. Our data allows us to support what is suggested in previous studies such as the ones published by Payne CLR et al. and Halloran et al. $[29,30]$. Which expose the viability for the use of insects to transform low value organic by-products into high value foods with very low greenhouse gas emissions.

In terms of fiber content, $U$. dermestoides presented a very high value $(49.17 \pm 0.32 \%)$ compared with the $22.1 \%$ reported by Jasso-Villagomez et al. [39]. When compared with other insect orders like Orthoptera, the difference in fiber content for $U$. dermestoides is more significant, for example, the grasshopper C. rosea has $12.38 \%$ of fiber content, while bush criket $B$. orientalis has only $8.75 \%$ $[33,38]$.

\section{Qualitative phytochemical analysis}

In the qualitative phytochemical analysis (Table 2), the presence of some secondary metabolites commonly associated with the antioxidant activity (tannins or flavonoids) were not found, neither in T. molitor nor $U$. dermestoides, this analysis was performed after the defatting of the insects in order to confirm that the antioxidant activity evaluated was only due to the protein fraction. Carbohydrates and reducing sugars were detected in both insects. Glucosides, flavonoids, alkaloids and steroids
Table 2 Qualitative phytochemical results of Tenebroideae beetles T.molitor and $U$. dermestoides

\begin{tabular}{llll}
\hline Phytochemical & Test performed & \multicolumn{2}{l}{ Insect aqueous extract } \\
\cline { 3 - 4 } & & U. dermestoides & T. molitor \\
\hline Tannins & & - & - \\
Saponins & Superficial foam & ++ & + \\
Glucosides & Keller-Kiliani & - & - \\
& Borntrager's & - & - \\
Carbohydrates & Molisch's & + & + \\
& Benedict's & + & + \\
& Fehling's & + & + \\
Flavonoids & Lead acetate & - & - \\
& Salkowski's: & - & - \\
& Shinoda & - & - \\
Proteins & Bradford & + & ++ \\
Alkaloids & Dragendorf's: & - & - \\
& Mayer's & - & - \\
& Wagner's & - & - \\
Steroids & Hager's: & - & - \\
Anthraquinones & Liebermann Burchard's & - & - \\
\cline { 3 - 4 } & & &
\end{tabular}

Values are expressed as positive $(+)$, very clear result $(++)$, negative $(-)$; not applicable (NA). Acidic extraction and alkaline extraction were used for alkaloids and steroids (nevertheless, no positive results were detected)

were absent using the procedures indicated for each test. Proteins were detected using Bradford reagent with both beetles; there was a major color intensity on the qualitative test of T. molitor in comparison with the test of $U$. dermestoides, in agreement with the nitrogen content estimated by the proximal analysis. The stable foam formation suggested the presence of saponins. No qualitative tests were considered as positive in this work for alkaloids, steroid or anthraquinones [40].

\section{Protein extract preparation}

Three buffering systems were used to evaluate the best extraction conditions for $U$. dermestoides and T. molitor insect proteins. Despite the differences in $\mathrm{pH}$ of the extraction systems (Citrate buffer pH 5, carbonate buffer pH 9 and PBS buffer pH 7), polyacrylamide gel denaturing electrophoresis (SDS PAGE), showed no significant differences in band patterns for the extracts (Fig. 1). We then decided to use PBS as a buffer for protein extraction. Spite the several replicates obtained by the sonication method (regardless of the buffer) on the extraction of $T$. molitor, the electrophoretic profile always showed few bands.The protein profile revealed by electrophoresis of both insects' crude extracts showed very different patterns and molecular weight bands. For $U$. dermestoides most of the bands center around $45 \mathrm{kDa}$; but there is 


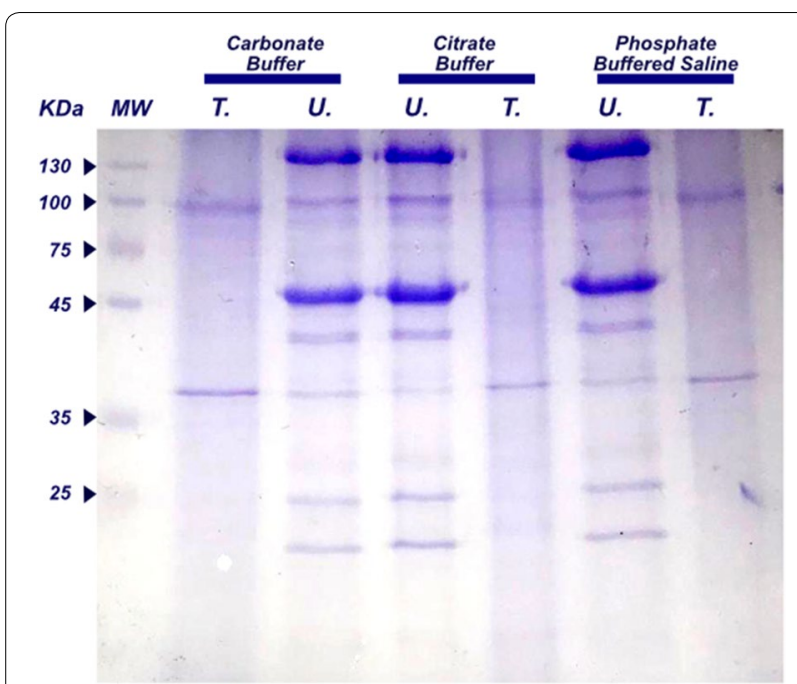

Fig. 1 SDS-PAGE of protein extracts from T. molitor and U. dermestoides adult insects. A 15\% of Tris Tricine SDS-PAGE gel is presented. There was no significant difference among the buffers tested in terms of protein band detection. Elecrophoresis shows better resolution of the bands for $U$. dermestoides extract in comparison with T. molitor's. Protein extracts show that the number of peptides present in the direct extraction is practically absent. MW: Protein Molecular Weight Marker in $\mathrm{KDa}$

a presence of low molecular bands between 25 and $15 \mathrm{kDa}$, and a very strong band around $130 \mathrm{kDa}$. By the other hand, very few bands were distinguishable in the T. molitor protein crude extracts, two strong bands: one near to $95 \mathrm{kDa}$ and the other around $37 \mathrm{kDa}$. This can be explained by the conditions used for the extraction in this work, where the selected buffers did not count with the presence of caothrophic agents such as urea or detergents as SDS or Triton, which contributed to the low protein extraction of T. Molitor.

These parameters where employed in urge to minimize further effects on the protein quantifications assays such as the digestion of crude extracts. It's worth mentioning that previous works reporting any electrophoretic profile where focused on the larvae stage of the insect [37] rather the adult stage, and, applying rougher extraction conditions (prolongated agitation [42], or extended sonication time [43]), conditions that we avoided in order to restrict the protein degradation in this work. Studies such as Zielińska et al. [11], state that the electrophoretic protein profile for a specified extraction may vary greatly due to changes on the conditions employed.

Although the methodology for protein extraction was not the same as in the protein profile previously reported for T. molitor, we were able to detect some of the bands present on those studies [12, 34, 35]; for example, the bands in the range of $32-95 \mathrm{KDa}$ in T. molitor were also obtained in this work, except no bands above $95 \mathrm{KDa}$ were detected as aforementioned studies report. [41].

\section{Protease digestion of PBS extract}

In order to explore the diversity of encrypted peptides we decided to achieve proteolysis of the PBS extracts from the $U$. dermestoides and T. molitor insects. Using an $A$. oryzae protease containing both endoprotease's and exopeptidase's activity, the PBS extracts were digested, and the peptide profile was analyzed with an optimized gel (Tris-Tricine SDS-Gel) for peptides [20]. Figure 2 shows in lane 1 the autoproteolysis control and in lane 2 the digested extract of $U$. dermestoides. It is possible to observe that the digested extract presents two major bands of peptides between 15 and $35 \mathrm{kDa}$ with differential bands compared to the autoproteolysis control, there is also a digested fraction under $15 \mathrm{kDa}$ present in the gel. Meanwhile T. molitor digested extract showed a range of 1.5-25 kDa peptide profile. No bands above $40 \mathrm{KDa}$ were detected for any of the digested extracts, and the protein profile is completely different respect to the total protein extracts.

Due to the use of a protease with both endo- and exopeptidase activities, as it is A. Oryzae, it is likely that the liberated fragments are attributable to an exhaustive proteolysis of the hemolymph proteins of the insects. It is reported for T. Molitor a defensin (small cationic cysteine rich peptide) [42], with a molecular weight below $10 \mathrm{kDa}$, known as tenecin-1 [43]. More experimental data is required for a detailed characterization of the peptides liberated throughout the process applied by fungal proteases as A. Oryzae, however, the approach of the encrypted peptides obtention process by this kind of proteases looks promising [42, 44].

\section{Total antioxidant capacity of protein insect extracts}

The antioxidant activities of the extracts were expressed as micromoles of Trolox/g insect (Fig. 3a). Protein concentrations were adjusted to obtain similar amounts of protein for the antioxidant activity test. If we compare PBS extract from $U$. dermestoides and $T$. molitor there was no statistically significant difference at $95 \%$ confidence interval by a student's $t$ test. Although, the antioxidant activity found for Tenebrio protein extract $(41.4 \pm 2.3 \mu \mathrm{mol}$ Trolox/g) and $U$. dermestoides protein extract $(54.8 \pm 3.1 \mu \mathrm{mol}$ Trolox/g) was less than the reported for fruits such as strawberry ( $358 \mu \mathrm{mol}$ Trolox/g), blueberries $(348.25 \mu \mathrm{mol}$ Trolox/g) and pomegranate peel and pulp (4.6-6.3 mM Trolox/g); higher than the water-soluble extracts of grasshoppers $(2.55+0.05 \mu \mathrm{mol}$ Trolox/g), silkworm $\quad(2.48+0.19 \mu \mathrm{mol} \quad$ Trolox/g), crickets $(2.37+0.03 \mu \mathrm{mol} \quad$ Trolox/g) and fresh orange juice $(0.40 \pm 0.01)$; and similar to the 


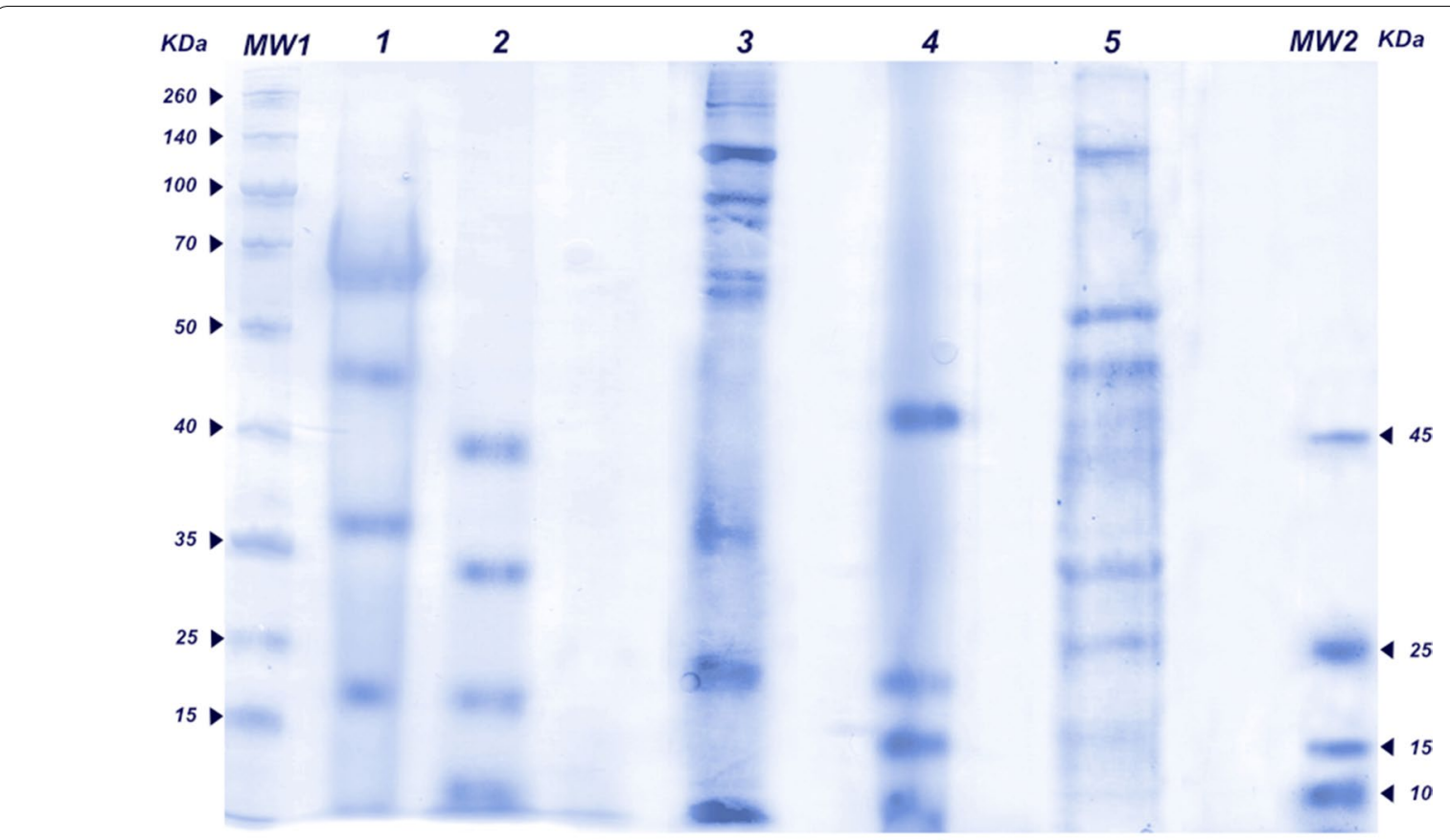

Fig. 2 Tris Tricine SDS-Gel with the hydrolysate U. dermestoides and T. molitor extract with A. oryzae protease. MW1. Protein marker (numbers indicate $\mathrm{KDa}$ ). Lane 1. Control of autoproteolysis with A. oryzae protease under the same conditions of digested extracts. Lane 2. Digested extract of U. dermestodies with A. oryzae protease. Lane 3. Non-digested extract of U. dermestoides in PBS. Lane 4. Digested extract of T. molitor with A. oryzae protease. Lane 5. Non-digested extract of T. molitor with PBS. MW2. Peptide protein marker (numbers indicate KDa)
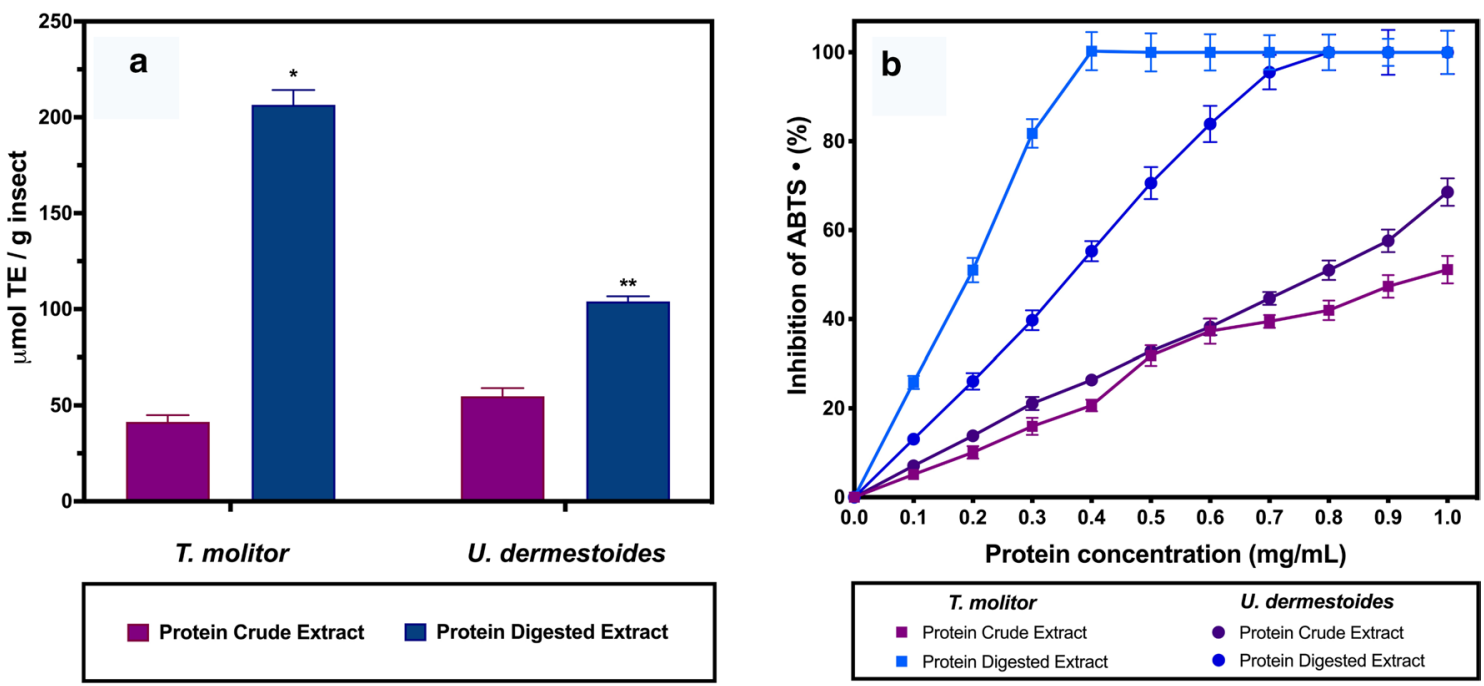

Fig. 3 Total antioxidant activity of the protein extract from U. dermestoides and T. molitor. a Comparison of the antioxidant activity of protein extracts before and after digestion with protease. The asterisks show that there is a statistical difference between the protein digested extract at 95\% of confidence. $\mathbf{b}$ Inhibition of ABTS radical assay with the non-digested and digested protein extract

activity found in freeze-dried peel of purple star apple (3310.95 $\mu \mathrm{M}$ Trolox/100 g DW) and yellow cashew (3322.31 $\mu \mathrm{M}$ Trolox/100 g DW) [43-45]. Nevertheless, the activity we obtained with the extract is referred exclusively to protein fraction per insect gram. Moreover, when a digestion with $A$. oryzae protease was performed on the protein crude extract, there was a significant increase on the total antioxidant capacity for the sample, 
Table 3 Antimicrobial activity of the enzymatic hydrolysates of protein extract from $U$. dermestoides and $T$. molitor against selected microorganisms

\begin{tabular}{lccccc}
\hline Protein digested extract & \multicolumn{2}{l}{ Diameter of growth inhibition zone $(\mathrm{mm})$} \\
\cline { 2 - 6 } & P. vulgaris & S. flexnerii & $\begin{array}{l}\text { Bacillus } t . \\
\text { subsp. Tenebrionis }\end{array}$ & $\begin{array}{l}\text { Bacillus } t . \\
\text { subsp. kenyae }\end{array}$ & Enzymatic control \\
\hline U. dermestoides & $9(+++)$ & $11(++++)$ & $13.5(++++)$ & $7.7(+++)$ & $<1(-)$ \\
T. molitor & $7.5(+++)$ & $12(++++)$ & $8.5(+++)$ & $5.5(++)$ & $<1(-)$
\end{tabular}

Each value is expressed as mean $(n=3)$ and standard deviations were less than $5 \%$. No antimicrobial activity $(-)$, inhibition zone $<1$ mm. Slight antimicrobial activity $(+)$, inhibition zone $2-3 \mathrm{~mm}$. Moderate antimicrobial activity $(++)$, inhibition zone $4-5 \mathrm{~mm}$. High antimicrobial activity $(+++)$, inhibition zone 6-9 mm. Strong antimicrobial activity $(++++)$, inhibition zone $>9 \mathrm{~mm}$. Standard deviation $\pm 0.4 \mathrm{~mm}$. The protein crude extracts showed no inhibition zone

reaching $206 \pm 8.5 \mu \mathrm{mol}$ Trolox/g for $T$. molitor extract and $104 \pm 6.2 \mu \mathrm{mol}$ Trolox/g for $U$. dermestoides extract respectively.

We evaluated the ABTS radical inhibition percentage (Fig. 3) using the insect protein extracts (PBS and protease digested). The results showed that a $100 \%$ of the ABTS radical inhibition was reached at approximately $0.4 \mathrm{mg} / \mathrm{mL}$ of protein for the digested extract of $T$. molitor and it takes $0.8 \mathrm{mg} / \mathrm{mL}$ of protein for the digested extract of $U$. dermestoides. When the PBS protein extracts were used no complete radical inhibition for either insect was achieved, under the kinetic conditions used. Even though both insects belong to the same family and were fed under the same diet, the kinetic profiles of the antioxidant activity were very different. In the case of the $U$. dermestoides digested extract, it took almost twice the amount of protein in order to achieve a $100 \%$ of the ABTS radical inhibition.

\section{Protease digestion of PBS extract for antimicrobial activity evaluation}

We decided to test if the hydrolysates obtained with the $A$. oryzae protease were able to inhibit the growth of some of the bacteria on a well diffusion method test. Only three microorganisms among the tested in our assay, presented inhibition by the digested extracts. Two gram negative microorganisms (P. vulgaris and Shigella flexnerii) and one gram positive (Bacillus spp) presented inhibition by the digested protein extracts of both insects. Results are summarized in Table 3. Extracts digested with protease open the possibility for the use of these beetles as a new source of encrypted peptides for microbiological control once characterized.

\section{Conclusion}

High fiber and protein content values were obtained with the diet supplied to insects during this work. Antioxidant activity for the protein crude extracts of $T$. molitor and $U$. dermestoides showed values around
41.4 and 54.8 $\mu \mathrm{mol}$ Troxol/g respectively, however once the extracts were digested with $A$. oryzae protease, the antioxidant activities increased to 206 for T. molitor and 104 for $U$. dermestoides. The digested extracts presented different kinetic patterns on the inhibition of ABTS radicals, where $U$. dermestoides needed twice as digested protein extract compared to T. molitor. These also showed antimicrobial activity against $P$. vulgaris, $S$. flexnerii and Bacillus spp. All this data suggests that $T$. molitor and $U$. dermestoides are an excellent possibility as sources of fiber and protein moreover their antioxidant properties make them suitable as nutraceutical food.

\section{Acknowledgements \\ To CONACyT (Consejo Nacional de Ciencia y Tecnología de México) for the Master scholarship 714080 of D.R.F, scholar number/590744.}

\section{Authors' contributions}

DRF and LEC carried out the experimental part. ACR performed antioxidant activity analysis. SFRV performed some of the experimental and language editing. GVJ wrote and edited the manuscript. All authors shared equally the revision of the manuscript. All authors read and approved the final manuscript.

\section{Funding}

The authors have no funding to report.

\section{Ethics approval and consent to participate}

Corresponding to the Mexican law on the protection of animals used for scientific purposes (NORMA Oficial Mexicana NOM-062-ZOO-1999), this article does not contain studies with animal subjects as experiments with insects or invertebrates are not classified as animal experiments.

\section{Competing interests}

The authors declare that they have no competing interests. All authors of the manuscript have read and agreed to its content and are accountable for all aspects of the accuracy and integrity of the manuscript. This article is original, has not already been published in a journal, and is not currently under consideration by another journal. Authors agree to the terms of the BioMed Central Copyright and License Agreement.

\section{Author details}

${ }^{1}$ Chemistry Department, University of Guadalajara, 1421 Marcelino García Barragán Blvd, 44430 Guadalajara, Jalisco, Mexico. ${ }^{2}$ Life and Science Division, Food Department, University of Guanajuato, Campus Irapuato-Salamanca, Km 9 carretera Irapuato-Silao ap 311, 36500 Irapuato, Guanajuato, Mexico. 


\section{References}

1. Akhtar Y, Isman MB (2018) Insects as an alternative protein source. Prot Food Proc. https://doi.org/10.1016/b978-0-08-100722-8.00011-5

2. Costa-Neto EM, Dunkel FV (2016) Insects as food: history, culture, and modern use around the World. Insects Sustain Food Ingred. https://doi. org/10.1016/b978-0-12-802856-8.00002-8

3. Caparros Megido R, Sablon L, Geuens M, Brostaux Y, Alabi T, Blecker C et al (2014) Edible insects acceptance by belgian consumers: promising attitude for entomophagy development. J Sens Stud. 29:14-20. https:// doi.org/10.1111/joss.12077

4. Dobermann D, Swift JA, Field LM (2017) Opportunities and hurdles of edible insects for food and feed. Nutr Bull. 42:293-308. https://doi. org/10.1111/nbu.12291

5. Veldkamp T, van Duinkerken G, van Huis A, lakemond C, Ottevanger $E$ Bosch G, et al. Wageningen UR Livestock Research Partner in livestock innovations Insects as a sustainable feed ingredient in pig and poultry diets-a feasibility study. 2012. http://www.livestockresearch.wur.nl. Accessed 18 Nov 2019

6. De Marco M, Martínez S, Hernandez F, Madrid J, Gai F, Rotolo L et al (2015) Nutritional value of two insect larval meals (Tenebrio molitor and Hermetia illucens) for broiler chickens: apparent nutrient digestibility, apparent ileal amino acid digestibility and apparent metabolizable energy. Anim Feed Sci Technol 209:211-218. https://doi.org/10.1016/J.ANIFEEDSCI .2015 .08 .006

7. Siemianowska E, Kosewska A, Aljewicz M, Skibniewska KA, Polak-Juszczak $\mathrm{L}$, Jarocki A, et al. Larvae of mealworm (Tenebrio molitor $L$ ) as European novel food. 2013:4:287-91. https://doi.org/10.4236/as.2013.46041

8. Ravzanaadii N, Kim S-H, Choi H, Hong S-J, Kim NJ (2012) Nutritional value of mealworm, tenebrio molitor as food source. Int J Indust Entomol. 25:93-98. https://doi.org/10.7852/ijie.2012.25.1.093

9. Crespo R, Villaverde ML, Girotti JR, Güerci A, Juárez MP, de Bravo MG (2011) Cytotoxic and genotoxic effects of defence secretion of Ulomoides dermestoides on A549 cells. J Ethnopharmacol 136:204-209. https://doi. org/10.1016/J.JEP.2011.04.056

10. Mendoza-Meza DL, España-Puccini P (2016) Cytotoxic and genotoxic activity of phenolic fractions from Ulomoides dermestoides FAIRMAIRE, 1893 (COLEOPTERA, TENEBRIONIDAE), IN HACAT CELLS. TIP. 19:83-91. https://doi.org/10.1016/J.RECQB.2016.06.001

11. Zielińska E, Baraniak B, Karaś M, Zielińska E, Baraniak B, Karaś M (2017) Antioxidant and anti-inflammatory activities of hydrolysates and peptide fractions obtained by enzymatic hydrolysis of selected heat-treated edible insects. Nutrients. 9:970. https://doi.org/10.3390/nu9090970

12. Tang Y, Debnath T, Choi E-J, Kim YW, Ryu JP, Jang S et al (2018) Changes in the amino acid profiles and free radical scavenging activities of Tenebrio molitor larvae following enzymatic hydrolysis. PLoS ONE 13:e0196218. https://doi.org/10.1371/journal.pone.0196218

13. Chevrolat LAA. Diagnoses de diapérides nouveaux. Petites Nouvelles Entomologiques. Premiere. 1878. https://www.biodiversitylibrary.org/ page/12392641\#page/7/mode/1up

14. Kim Jl, Jung BH (2005) Contribution to the Tribes Diaperini Doyen in Korea (Coleoptera: tenebrionidae: Diaperinae). Entomol Res. 35:95-100. https://doi.org/10.1111/j.1748-5967.2005.tb00142.x

15. Mariod AA, Saeed Mirghani ME, Hussein I, Mariod AA, Saeed Mirghani ME, Hussein I (2017) Tenebrio molitor Mealworm. Unconv Oilseeds Oil Sour. https://doi.org/10.1016/b978-0-12-809435-8.00050-0

16. Horwitz, W. and Latimer GW. Official methods of analysis of AOAC International. 18th Edition,. Assoc Off Anal Chem Int Maryland. 2006

17. Nobre CB, Sousa EO, Camilo CJ, Machado JF, Silva JMFL, Filho JR et al (2018) Antioxidative effect and phytochemical profile of natural products from the fruits of "babaçu" (Orbignia speciose) and "buriti" (Mauritia flexuosa). Food Chem Toxicol 121:423-429. https://doi.org/10.1016/J. FCT.2018.08.068

18. Aiyegoro OA, Okoh Al (2010) Preliminary phytochemical screening and In vitro antioxidant activities of the aqueous extract of Helichrysum longifolium DC. BMC Complement Altern Med. 10:21. https://doi. org/10.1186/1472-6882-10-21

19. Harborne JB 1998 (Jeffrey B. Phytochemical methods : a guide to modern techniques of plant analysis. Chapman and Hall

20. Ayoola GA, Coker HAB, Adesegun SA, Adepoju-bello AA, Obaweya K, Ezennia EC et al (2008) Phytochemical Screening and Antioxidant
Activities of Some Selected Medicinal Plants Used for Malaria Therapy in Southwestern Nigeria. Trop J Pharm Res 7:1019-1024

21. Kapoor LD, Singh A, Kapoor SL, Srivastava SN (1969) Survey of Indian medicinal plants for saponins, alkaloids and flavonoids. Lloydia. 32:297-302

22. Christensen BV, Abdel-Latif IA (1949) Colorimetric and fluorometric studies on the Borntraeger reaction for anthraquinone drugs. J Am Pharm Assoc. 38(9):487-489

23. Schägger H (2006) Tricine-SDS-PAGE. Nat Protoc 1:16-22. https://doi. org/10.1038/nprot.2006.4

24. Bradford MM (1976) A rapid and sensitive method for the quantitation of microgram quantities of protein utilizing the principle of protein-dye binding. Anal Biochem 72:248-254. https://doi.org/10.1016/00032697(76)90527-3

25. Re R, Pellegrini N, Proteggente A, Pannala A, Yang M, Rice-Evans C (1999) Antioxidant activity applying an improved ABTS radical cation decolorization assay. Free Radic Biol Med. 26:1231-1237. https://doi.org/10.1016/ S0891-5849(98)00315-3

26. de la Fuente-Salcido NM, Barboza-Corona JE, Espino Monzón AN, Pacheco Cano RD, Balagurusamy N, Bideshi DK et al (2012) Expanding the use of a fluorogenic method to determine activity and mode of action of Bacillus thuringiensis bacteriocins against Gram-positive and Gram-negative bacteria. ScientificWorldJournal. 2012:503269. https://doi. org/10.1100/2012/503269

27. Al-Thubiani ASA, Maher YA, Fathi A, Abourehab MAS, Alarjah M, Khan MSA et al (2018) Identification and characterization of a novel antimicrobial peptide compound produced by Bacillus megaterium strain isolated from oral microflora. Saudi Pharm J. 26:1089-1097

28. Durst PB, Johnson DV, Leslie RN, Shono K 2010 Forest insects as food: humans bite back Proceedings of a workshop on Asia-Pacific resources and their potential for development

29. Mlcek J, Rop O, Borkovcova M, Bednarova M (2014) A comprehensive look at the possibilities of edible insects as food in Europe-a |review. Polish J Food Nutr Sci. 64:147-157

30. Payne CLR, Scarborough P, Rayner M, Nonaka K (2016) Are edible insects more or less "healthy" than commonly consumed meats? A comparison using two nutrient profiling models developed to combat over- and undernutrition. Eur J Clin Nutr 70:285-291

31. Halloran A, Flore R, Vantomme P, Roos N 2018 Edible Insects in Sustainable Food Systems. Edible Insects Sustain Food Syst. 1-479

32. van Huis A, Oonincx DGAB (2017) The environmental sustainability of insects as food and feed. A review. Agron Sustain Develop. 37:43

33. Chakravorty J, Ghosh S, Jung C, Meyer-Rochow VB (2014) Nutritional composition of Chondacris rosea and Brachytrupes orientalis: two common insects used as food by tribes of Arunachal Pradesh, India. J Asia Pac Entomol. 17:407-415. https://doi.org/10.1016/j.aspen.2014.03.007

34. Zhou R, Chen L (2006) Determination of nutritional components of in Palembus dermestoides. Chinese Bull Entomol. 43:684-687

35. Kim SK, Weaver CM, Choi MK (2017) Composición aproximada y contenido mineral de cinco insectos comestibles consumidos en Corea. CYTAJ Food. 15:143-146. https://doi.org/10.1080/19476337.2016.1223172

36. Adámková A, Kourimská L, Borkovcová M, Kulma M, Mlček J (2016) Nutritional values of edible Coleoptera (Tenebrio molitor, Zophobas morio and Alphitobius diaperinus) reared in the Czech Republic. Potravinarstvo. 10:663-671

37. Roos N 2018 Insects and human nutrition. In: Edible Insects in Sustainable Food Systems. Springer International Publishing. p. 83-91

38. Ghosh S, Lee SM, Jung C, Meyer-Rochow VB (2017) Nutritional composition of five commercial edible insects in South Korea. J Asia Pac Entomol. 20:686-694. https://doi.org/10.1016/j.aspen.2017.04.003

39. Jasso-Villagomez El, Garcia-Lorenzana M, Almanza-Perez JC, Fortis-Barrera MA, Blancas-Flores G, Roman-Ramos R, et al 2018 Beetle (Ulomoides dermestoides) fat improves diabetes: Effect on liver and pancreatic architecture and on PPARy expression. Brazilian J Med Biol Res. 51

40. Selvakumar P, Sivashanmugam P (2019) Ultrasound assisted oleaginous yeast lipid extraction and garbage lipase catalyzed transesterification for enhanced biodiesel production. Energy Convers Manag. 179:141-151. https://doi.org/10.1016/J.ENCONMAN.2018.10.051

41. Yi L, Lakemond CMM, Sagis LMC, Eisner-Schadler V, van Huis A, van Boekel MAJS (2013) Extraction and characterisation of protein fractions 
from five insect species. Food Chem 141:3341-3348. https://doi. org/10.1016/J.FOODCHEM.2013.05.115

42. Yi H-Y, Chowdhury M, Huang Y-D, Yu X-Q (2014) Insect antimicrobial peptides and their applications. Appl Microbiol Biotechnol 98:5807-5822. https://doi.org/10.1007/s00253-014-5792-6

43. Di Mattia C, Battista N, Sacchetti G, Serafini M (2019) Antioxidant activities in vitro of water and liposoluble extracts obtained by different species of edible insects and invertebrates. Front Nutr. 6:1-7

44. Singh JP, Kaur A, Shevkani K, Singh N (2016) Composition, bioactive compounds and antioxidant activity of common Indian fruits and vegetables. J Food Sci Technol 53:4056-4066
45. Moo-Huchin VM, Moo-Huchin MI, Estrada-León RJ, Cuevas-Glory L, Estrada-Mota IA, Ortiz-Vázquez E et al (2015) Antioxidant compounds, antioxidant activity and phenolic content in peel from three tropical fruits from Yucatan. Mexico. Food Chem. 166:17-22. https://doi.org/10.1016/j. foodchem.2014.05.127

\section{Publisher's Note}

Springer Nature remains neutral with regard to jurisdictional claims in published maps and institutional affiliations.
Ready to submit your research? Choose BMC and benefit from:

- fast, convenient online submission

- thorough peer review by experienced researchers in your field

- rapid publication on acceptance

- support for research data, including large and complex data types

- gold Open Access which fosters wider collaboration and increased citations

- maximum visibility for your research: over $100 \mathrm{M}$ website views per year

At BMC, research is always in progress.

Learn more biomedcentral.com/submissions 